AperTO - Archivio Istituzionale Open Access dell'Università di Torino

Stand structural complexity of mixed old-growth and adjacent selection forests in the Dinaric Mountains of Bosnia and Herzegovina

This is a pre print version of the following article:

Original Citation:

Availability:

This version is available http://hdl.handle.net/2318/1657791

since 2018-01-16T18:05:05Z

Published version:

DOI:10.1016/j.foreco.2017.06.009

Terms of use:

Open Access

Anyone can freely access the full text of works made available as "Open Access". Works made available under a Creative Commons license can be used according to the terms and conditions of said license. Use of all other works requires consent of the right holder (author or publisher) if not exempted from copyright protection by the applicable law. 


\title{
Stand structural complexity of mixed old-growth and adjacent selection managed forests in the Dinaric Mountains of Bosnia and Herzegovina
}

\author{
Srđan Keren ${ }^{1,4^{*}}$, Jurij Diaci ${ }^{2}$, Renzo Motta ${ }^{3}$, Zoran Govedar ${ }^{4}$ \\ ${ }^{1}$ Faculty of Forestry, University of Agriculture, al. 29-Listopada 46, 31-425 Krakow, Poland \\ ${ }^{2}$ Department of Forestry and Renewable Forest Resources, Biotechnical Faculty, University of Ljubljana, Vecna \\ pot 83, Ljubljana 1000, Slovenia \\ ${ }^{3}$ Department of Agriculture, Forestry and Food sciences, University of Turin, via Leonardo da Vinci, Grugliasco \\ 44 , Italy \\ ${ }^{4}$ Faculty of Forestry, University of Banja Luka, Bulevar Stepa Stepanovic 75, 78000 Banja Luka, Bosnia and \\ Herzegovina \\ *Corresponding author. E-mail: s.keren@ur.krakow.pl
}

\begin{abstract}
Single-tree selection system is considered as the earliest form of nature-based silviculture. However, due to the fact that only few old-growth forests (OGF) are left in Europe, the comparisons between OGF and selection-managed forests (MF) were rarely possible. Moreover, research results on structures of European OGF are often contradictory; while some researchers stress equilibrium structures (e.g. negative-exponential dbh distribution) in a small scale, others suggest that this rarely happens due to biomass accumulation. If the former is the case, then the argument that OGF should serve as natural references for selection management would be fairly strong. At the same time, mountain mixed selection forests are in many regions thought of as the most "natural" type of MF, and thus, similar to large extent to corresponding OGF. The concerns have been recently raised, however, whether selection system provides conditions favorable enough for maintenance of all constituent tree species on a given site. Since nature-based silviculture should follow natural processes and not exclude any species from their natural range, in this study we compared two mixed mountainous OGF and neighboring MF in Bosnia-Herzegovina across the same forest type (Piceo-Abieti-Fagetum illyricum). The MF were managed using single-tree selection for almost one century. The results indicated that this management approach yielded statistically tangible difference in tree species composition and presence of large-diameter trees. However, despite high values of growing stock, cumulative diameter distributions in both OGF and MF had shapes that are considered to provide demographic equilibrium. While at the species level this was the case only for beech. Species occurrence matrices indicated significant domination of European beech (Fagus sylvatica L.) young trees over silver fir (Abies alba Mill.) and Norway spruce (Picea abies L. Karst) in OGF. Nevertheless, based on the results from MF, the study highlights the crucial role of silvicultural measures which potentially may provide targeted long-term coexistence of studied broadleaved and coniferous tree species.
\end{abstract}

Key words: mixed old-growth forests, selection managed forests, stand structure, species diversity

\section{Introduction}

After disastrous consequences that followed the application of clear-cut forest management in mountains of central Europe in mid- $19^{\text {th }}$ century, many forest scientists shifted their research towards alternative silvicultural systems (Schütz, 1999). One of the first widely applied alternative was selection (plenter) system which introduced demographic sustainability on a very small scale, namely on a stand level (Schütz, 2001). The range of alternative (nature-based) systems was later supplemented by the irregular shelterwood (Matthews, 1999). While during the 
last century share of forests managed by the alternative silvicultural systems rather slowly increased, recently not only foresters, but also ecologists have become disposed towards the idea of nature-based silviculture (Pukkala \& Gadow, 2012; Puettmann et al., 2015). Good example in a sense of "return to nature" seems to be Germany which has made large efforts regarding conversion of monocultures into mixed stands (Spathelf et al. 2015). On the other hand, forest management in countries of south-eastern Europe was not so intensive in the past as in central Europe. For instance, older documents indicate that at the beginning of the 20th century more than $50 \%$ of forests in Bosnia-Herzegovina were pristine forests (Fröhlich, 1954). Although during the first half of that century the old-growth forests (OGF) were gradually converted into managed, mostly selection forests (MF) over large areas in this country, a few untouched remnants have been preserved to the present day.

There are nowadays scientifically justified proposals across Europe to increase structural diversity and preserve tree species diversity on a landscape level (e.g. Pach \& Podlaski, 2015; Schütz et al., 2016). Achieving such goals in the past was often hampered for reasons such as fast production and short-term profitability, but even when the old obstacles are removed, recently the changing climate became globally acknowledged as one of the main determinants of the development of forest ecosystems (Kovats et al., 2014). Under the ongoing changes even mixed OGF, that are generally believed to be compositionally stable, seem to struggle to maintain compositional stability as several studies indicated progression of European beech (Fagus sylvatica L.) and decline of conifers in different European countries (e.g. Bolte et al., 2010; Diaci, 2011; Szwagrzyk et al., 2012; Keren et al., 2014).

On the other hand, development of managed stands aside from environmental factors depends largely on silvicultural approach. Although selection system has provided sustained yield in MF so far, following the Rio summit in 1992 the sustained yield approach has been widely questioned by concern over sustainability of the entire ecological system, consisting of ecosystem structures, functions, goods and services (Kimmins et al., 2007). Consequently, forest managers are nowadays facing variety of old and new demands, while nature-based silviculture often comes as a proposal for solving contradictory stakeholders' interests. Owing to this fact, comparison of structural and ecological characteristics between OGF and adjacent MF could provide the answer to what extent and if at all the applied system in MF goes along with nature or not. Unfortunately, there are only few pristine forests remnants left untouched in Europe, and therefore the studies of OGF characteristics and their comparisons with MF have been more rarity than rule. Due to the lack of comparative type of managed vs. unmanaged forests research, we are currently lacking the knowledge on natural forest development, and likewise on the differences between natural forest structures and those that occurred as a result of selection silviculture.

O'Hara \& Gersonde (2004) indicated that the most common approach for stocking control in North-American selection MF describes the desirable (equilibrium) stand structure with a negative exponential or reverse-J diameter distribution, which in Europe is often called plenter structure. We would assume that in case the OGF really exhibit such structure, then setting it as a management goal for MF would be a strong argument from the point of nature-based silviculture. Nevertheless, Korpel (1995) stated that due to biomass accumulation the plenter structure is rarely found in natural forests. Similarly, Schütz (2002a) indicated that plenter forests 
if unexploited over a long period would probably evolve slowly towards uniformity and for that reason intensive and recurring silvicultural interventions would be necessary in order to maintain plenter structure. (Goff and West, 1975; Alessandrini et al., 2011)

Angers et al. (2005) stated that single-tree selection system is similar to natural gap disturbance regime in OGF, hence, both provide structural- and species diversity. However, there is still a lack of evidence to what extent selection management follows the structures and tree species composition of natural primeval OGF. The information on this issue is scarce in Europe as only few studies were focused on the comparison of stand structural parameters between selectionmanaged MF and corresponding OGF (e.g., Bončina et al., 2014; Motta et al.. 2015; Adamic et al., 2016). If management is nature-based, then we would expect that the structure and species composition in MF resemble those found in neighboring OGF. Therefore, we addressed the above described problems in the present study by comparing two Bosnian OGF of pristine character with adjacent selection-managed MF in terms of (i) structural diversity including the presence of developmental phases and the analyses of diameter distribution shapes, and (ii) tree species composition and mixing patterns.

\section{Methods}

\subsection{Study site}

The research was conducted in two OGF Janj and Lom, and ten adjacent selection-managed forest stands in Bosnian Dinaric Mountains (Table 1). Among those managed stands five of them (31a, 50d, 56, 57/1b, 58a) were chosen on the comparable basis in the close proximity of OGF Janj, whereas another five managed stands (59a, 67a, 68a, 76a, 79a) were surveyed in the close proximity of OGF Lom. All research sites were classified as forest association Piceo-AbietiFagetum illyricum (dinaricum) that actually represents the mixture of European beech, silver fir (Abies alba Mill.) and Norway spruce (Picea abies (L.) Karst) with small shares of noble broadleaves. Selection management within the research area has been applied from the early 20th century. At the beginning it was more traditionally oriented (Hufnagel 1893), but after WWII it was based on the principles of control method (Biolley, 1901; Matic, 1963). The geographic position of OGF Janj core area (57.2 ha) is located at $44^{\circ} 08^{\prime} \mathrm{N}, 17^{\circ} 17^{\prime} \mathrm{E}$, and OGF Lom core area $(55.8 \mathrm{ha})$ is located at $44^{\circ} 27^{\prime} \mathrm{N}, 16^{\circ} 27^{\prime} \mathrm{E}$. Core areas of both OGF are surrounded with buffer zones (Janj 237.8 ha, Lom 297.8 ha). In OGF Janj mean annual rainfall amounts to 1200 $\mathrm{mm}$ and mean annual temperature is around $5{ }^{\circ} \mathrm{C}$, whereas for OGF Lom respective precipitation and temperature values are $1600 \mathrm{~mm}$ and $7.8^{\circ} \mathrm{C}$ (Drinic station, $730 \mathrm{~m}$ a.s.1.). The game density may significantly limit the recruitment of some species such as fir (Ficko et al., 2016), but probably due to excessive hunting in last several decades the damage on regeneration in the study area was negligible.

The criterions for choosing managed stands were the environmental characteristics (site conditions, aspect, etc.) which had to be similar to those of OGF. Furthermore, the cutting intensity was typical for selection system (it did not exceed $20 \%$ of the growing stock), and the last cut was carried out at least four years before the field work. This system has long tradition in the study area, and it is to this day the most preferred by domestic foresters. Careful attention is given to the selection of trees for cutting; namely, every tree with diameter at breast height 
(DBH) $>7 \mathrm{~cm}$ was marked in the field few months before the actual cutting took place. It is thereby important to notice that regulation of species composition and tending below inventory threshold $(<7 \mathrm{~cm} \mathrm{DBH})$ is not performed, which means that regeneration develops "freely". However, it is also important to emphasize that within the applied plenter system in Bosnian forests the regulation of tree species composition plays significant role, hence, young beech trees having 7-25(30) $\mathrm{cm}$ DBH are usually cut more intensively than same-sized conifers.

Table 1. Study site characteristics of OGF Janj and Lom and neighboring managed stands.

\begin{tabular}{|c|c|c|c|c|c|c|c|}
\hline $\begin{array}{l}\text { Research } \\
\text { objects }\end{array}$ & $\begin{array}{l}\text { Altitude } \\
\text { (m a.s.1.) }\end{array}$ & $\begin{array}{c}\text { Inclination } \\
\left({ }^{\circ}\right)\end{array}$ & Exposure & Bedrock & Soil type & $\begin{array}{c}\text { Rocky } \\
\text { outcrops } \\
(\%)\end{array}$ & $\begin{array}{c}\text { Soil } \\
\text { Humidity }\end{array}$ \\
\hline OGF Janj & $1240-1400$ & $0-10$ & $\begin{array}{l}\text { north- } \\
\text { western }\end{array}$ & dolomite & $\begin{array}{l}\text { brown soil } \\
\text { and rendzina }\end{array}$ & 0 & moderate \\
\hline Janj stand 31a & $1300-1400$ & $5-10$ & $\begin{array}{l}\text { north- } \\
\text { eastern }\end{array}$ & $\begin{array}{l}\text { dolomite and } \\
\text { limestone }\end{array}$ & $\begin{array}{c}\text { deep brown } \\
\text { soil }\end{array}$ & $0-5$ & moderate \\
\hline Janj stand 50d & $1250-1365$ & 10 & $\begin{array}{l}\text { north- } \\
\text { western }\end{array}$ & $\begin{array}{l}\text { dolomite and } \\
\text { limestone }\end{array}$ & $\begin{array}{l}\text { deep brown } \\
\text { soil }\end{array}$ & $0-5$ & moderate \\
\hline Janj stand 56 & $1250-1372$ & 5 & $\begin{array}{c}\text { virtually } \\
\text { even terrain }\end{array}$ & $\begin{array}{l}\text { dolomite and } \\
\text { limestone }\end{array}$ & $\begin{array}{l}\text { deep brown soil } \\
\text { and rendzina }\end{array}$ & $0-10$ & $\begin{array}{c}\text { dry to } \\
\text { moderate }\end{array}$ \\
\hline Janj stand $57 / 1 \mathrm{~b}$ & $1250-1380$ & $5-10$ & $\begin{array}{l}\text { north- } \\
\text { eastern }\end{array}$ & $\begin{array}{l}\text { dolomite and } \\
\text { limestone }\end{array}$ & $\begin{array}{l}\text { deep brown soil } \\
\text { and rendzina }\end{array}$ & $0-10$ & $\begin{array}{l}\text { dry to } \\
\text { moderate }\end{array}$ \\
\hline Janj stand 58a & $1250-1376$ & $5-10$ & $\begin{array}{l}\text { north- } \\
\text { eastern }\end{array}$ & $\begin{array}{l}\text { dolomite and } \\
\text { limestone }\end{array}$ & $\begin{array}{l}\text { deep brown } \\
\text { soil }\end{array}$ & $0-5$ & $\begin{array}{l}\text { dry to } \\
\text { moderate }\end{array}$ \\
\hline OGF Lom & $1250-1522$ & $5-10$ & northern & limestone & $\begin{array}{l}\text { deep and shallow } \\
\text { brown soils }\end{array}$ & 15 & moderate \\
\hline Lom stand 59a & 1000 & $4-7$ & $\begin{array}{l}\text { north- } \\
\text { western }\end{array}$ & mostly limestone & $\begin{array}{c}\text { deep brown } \\
\text { soil }\end{array}$ & $0-5$ & moderate \\
\hline Lom stand $67 \mathrm{a}$ & 1000 & $5-10$ & $\begin{array}{l}\text { north- } \\
\text { eastern }\end{array}$ & $\begin{array}{l}\text { limestone and } \\
\text { dolomite }\end{array}$ & $\begin{array}{c}\text { deep brown } \\
\text { soil }\end{array}$ & 0 & moderate \\
\hline Lom stand $68 \mathrm{a}$ & 1040 & $5-10$ & $\begin{array}{l}\text { north- } \\
\text { eastern }\end{array}$ & $\begin{array}{l}\text { limestone and } \\
\text { dolomite }\end{array}$ & $\begin{array}{c}\text { deep brown } \\
\text { soil }\end{array}$ & 0 & moderate \\
\hline Lom stand $76 a$ & $1100-1350$ & $5-7$ & $\begin{array}{l}\text { north- } \\
\text { eastern }\end{array}$ & $\begin{array}{l}\text { limestone and } \\
\text { dolomite }\end{array}$ & $\begin{array}{l}\text { deep and shallow } \\
\text { brown soils }\end{array}$ & $5-10$ & moderate \\
\hline Lom stand 79a & $1100-1450$ & 15 & $\begin{array}{c}\text { north- } \\
\text { western }\end{array}$ & $\begin{array}{l}\text { limestone and } \\
\text { dolomite }\end{array}$ & $\begin{array}{l}\text { deep and shallow } \\
\text { brown soils }\end{array}$ & $0-5$ & moderate \\
\hline
\end{tabular}

\subsection{Data collection}

Regular $100 \mathrm{~m}$ grids in the core areas of OGF Janj and Lom were superimposed resulting in 80 sampling plots (40 in each of them). In each managed stand 12 plots were set so that total number of plots in both MF was 120. The centers of plots in MF were distanced at least $25 \mathrm{~m}$ away from nearest forest roads. Each grid intersection defined the center of a sampling plot where the following inventories were carried out: in a $452 \mathrm{~m}^{2}$ circular plot (radius $=12 \mathrm{~m}$ ) species DBH (to the nearest $0.01 \mathrm{~m}$ ) for all living trees above $7.5 \mathrm{~cm}$ was measured; heights of living trees were measured (to the nearest $0.5 \mathrm{~m}$ ) for a sample of 100 trees for each species (spruce, fir and beech); in a $78.5 \mathrm{~m}^{2}$ circular plot (radius $=5 \mathrm{~m}$ ) species and height of regeneration individuals from $10 \mathrm{~cm}$ height to $7.5 \mathrm{~cm}$ diameter at breast height (DBH) were tallied. Field work was carried out in years 2011 and 2012. 
The following six development phases were distinguished: pole phase, optimal early -, optimal middle -, optimal late phase, selection phase, and terminal phase. Early-, middle-, and late optimal phase, as well as terminal phase, were identical to those described by Bončina (2000). Pole phase was broadly characterized by even-aged structure and dominance of young trees with $\mathrm{DBH}$ from $7.5 \mathrm{~cm}$ to $27.5 \mathrm{~cm}$. All phases were easily distinguishable except selection phase that resembles to certain degree early- and/or middle optimal stage, and thus may be misclassified (Kral et al., 2010). Therefore, we additionally used Mitscherlich's approach (1952) for distinguishing selection phase from early- and middle optimal stage. This approach proved to be suitable for small plots as we gained the insight in diameter distribution of each plot. Accordingly, the plots on which the number of small trees $(7.5-27.5 \mathrm{~cm})$ ranged from 100 to 700 , medium trees $(27.5-47.5 \mathrm{~cm})$ from 50 to 300 , and number of thick trees $(>47.5 \mathrm{~cm})$ was less than 70, all expressed per hectare, were grouped into selection phase category.

\subsection{Data analyses}

The shapes of DBH distributions were analyzed using the best-fitting models for multiple regressions between the base 10 logarithm of trees per hectare and all possible combinations of $\mathrm{DBH}, \mathrm{DBH}^{2}$ and $\mathrm{DBH}^{3}$. Detailed description was provided by Janowiak et al. (2008). Since 5 $\mathrm{cm}$ DBH class span (width) caused large fluctuations in OGF structure, for this analysis the class span of $10 \mathrm{~cm}$ was applied as suggested by Tyrrell \& Crow (1994). In addition, for assessing structural diversity the diameter differentiation indexes and species intermingling indexes were calculated (sensu Füldner 1995; 1996). Additionally, the differences in coefficients of DBH variation $(\mathrm{CV})$ on plot level were tested with independent t-tests at $\alpha=0.05$. In order to distinguish between pure (monospecific) and mixed plots, the following rule was applied: if the number of trees or basal area (BA) of one species exceeded $80 \%$ of the total tree number or total BA of the plot, then such plot would be classified as pure plot. Differences in tree species composition among OGF and MF were tested with two-variable $\chi^{2}$ test at $\alpha=0.05$.

Considering species occurrence patterns in the vertical stand profile, three stand-layer matrices were created in order to avoid possible oversimplification of data analysis as advised by White $e t$ al. (1985). Hence, relative tree species abundance in each sample plot was compared for the following stand layers: (1) regeneration from $10 \mathrm{~cm}$ in height to $7.5 \mathrm{~cm} \mathrm{DBH}$ (understory), (2) small trees with DBH from $7.5 \mathrm{~cm}$ to $27.5 \mathrm{~cm}$ (middle-story), and (3) canopy trees with $\mathrm{DBH}$ over $27.5 \mathrm{~cm}$ (upper-story). Based on such division, the occurrence matrices were constructed based on: a) the proportions of regeneration to middlestory and upperstory trees, and b) the proportions of middlestory to upperstory trees. Those relative frequencies (proportions) were finally averaged across all plots for each studied forest. Due to varied assumptions of these models, which were difficult to verify and since we did not sample regeneration below each single tree but rather on small sampling plots, we focused only on the most obvious relationships.

The volumes of living trees (comprising whole stem with branches and twigs) were calculated by using the local volume tables for beech, fir and spruce forests in Bosnia (Drinic et al., 1980). The generalized linear multivariate (GLM) analysis was applied in order to determine the influence of different species BA on the ingrowth of regeneration from $10 \mathrm{~cm}$ up to $2 \mathrm{~m}$ height and regeneration from $2 \mathrm{~m}$ height up to $7.5 \mathrm{~cm}$ DBH. General additive model (GAM) was used after 
separating only plots from OGF in order to determine the influence of BA of upperstory trees $(>27.5 \mathrm{~cm} \mathrm{DBH})$ on the number of small middlestory trees $(7.5-27.5 \mathrm{~cm} \mathrm{DBH})$. All statistical analyses were conducted in the StatSoft software package STATISTICA 12.

\section{Results}

\subsection{Structural characteristics}

OGF Janj had highest GS with $1215.1( \pm 54.9) \mathrm{m}^{3} /$ ha, second most stocked was OGF Lom with $763.1( \pm 31.2) \mathrm{m}^{3} /$ ha, while MF Lom and Janj followed with $664.3( \pm 26.2) \mathrm{m}^{3} /$ ha and $499( \pm 17.0)$ $\mathrm{m}^{3} /$ ha, respectively (Table 2). The late optimal phase in OGF Janj was predominant on $42.5 \%$ of the area, while in OGF Lom selection phase dominated on $37.5 \%$ and terminal phase on $20 \%$ of the area. Plots in MF Lom had selection phase in 50\% of cases, whereas in MF Janj plots were most often characterized with optimal early (45\%) and selection phase (33\%). The absolute number of plots with different developmental phases is given in Table 3.

Table 2. Tree density and growing stock (GS) per species and total in the study area for trees $>7 \mathrm{~cm} \mathrm{DBH}$

\begin{tabular}{ccccccc}
\hline & & Beech & Fir & Spruce & Maple & Total \\
\hline \multirow{2}{*}{$\begin{array}{c}\text { Tree density } \\
\text { (n/ha) }\end{array}$} & OGF Janj & 328 & 117 & 72 & 0 & 516 \\
& MF Janj & 176 & 328 & 165 & 11 & 681 \\
& OGF Lom & 296 & 122 & 69 & 2 & 489 \\
\hline & MF Lom & 213 & 208 & 157 & 17 & 594 \\
\hline GS & OGF Janj & 191.6 & 647.6 & 376.0 & 0 & 1215.1 \\
$\left(\mathrm{~m}^{3} / \mathrm{ha}\right)$ & MF Janj & 117.5 & 238.2 & 139.2 & 4.0 & 498.9 \\
& OGF Lom & 213.0 & 366.1 & 178.3 & 5.7 & 763.1 \\
& MF Lom & 104.7 & 203.7 & 341.6 & 14.1 & 664.2 \\
\hline
\end{tabular}

Table 3. The number of plots with different development phases.

\begin{tabular}{ccccc}
\hline Developmental phases & OGF Janj & MF Janj & OGF Lom & MF Lom \\
\hline Pole & - & 5 & - & 3 \\
Selection & 6 & 20 & 15 & 30 \\
Optimal early & 2 & 27 & 5 & 13 \\
Optimal middle & 6 & 8 & 5 & 14 \\
Optimal late & 17 & - & 7 & - \\
Terminal & 9 & - & 8 & - \\
\hline Total & 40 & 60 & 40 & 60 \\
\hline
\end{tabular}

MF and OGF had rather similar DBH distribution shapes, however, they universally differed in a way that smallest $\mathrm{DBH}$ class on both sites contained more trees in MF, whereas the presence of trees with DBH above $50 \mathrm{~cm}$ was greater in OGF (Fig. 1). The distribution of diameters in OGF Janj was dominated by beech within small diameter classes, but its share sharply declined towards medium and large diameter classes. Large diameter classes were dominated by fir and spruce in both OGF. 
Janj area
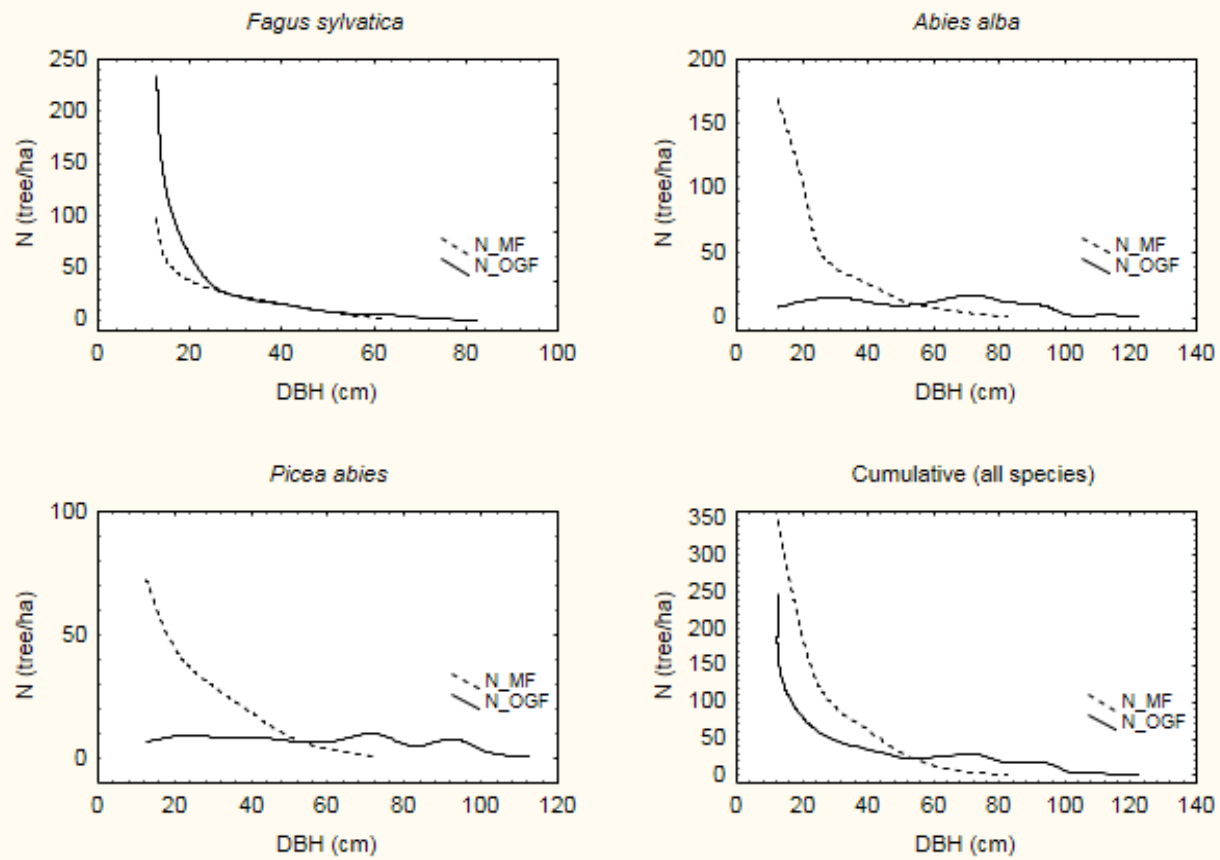

Lom area
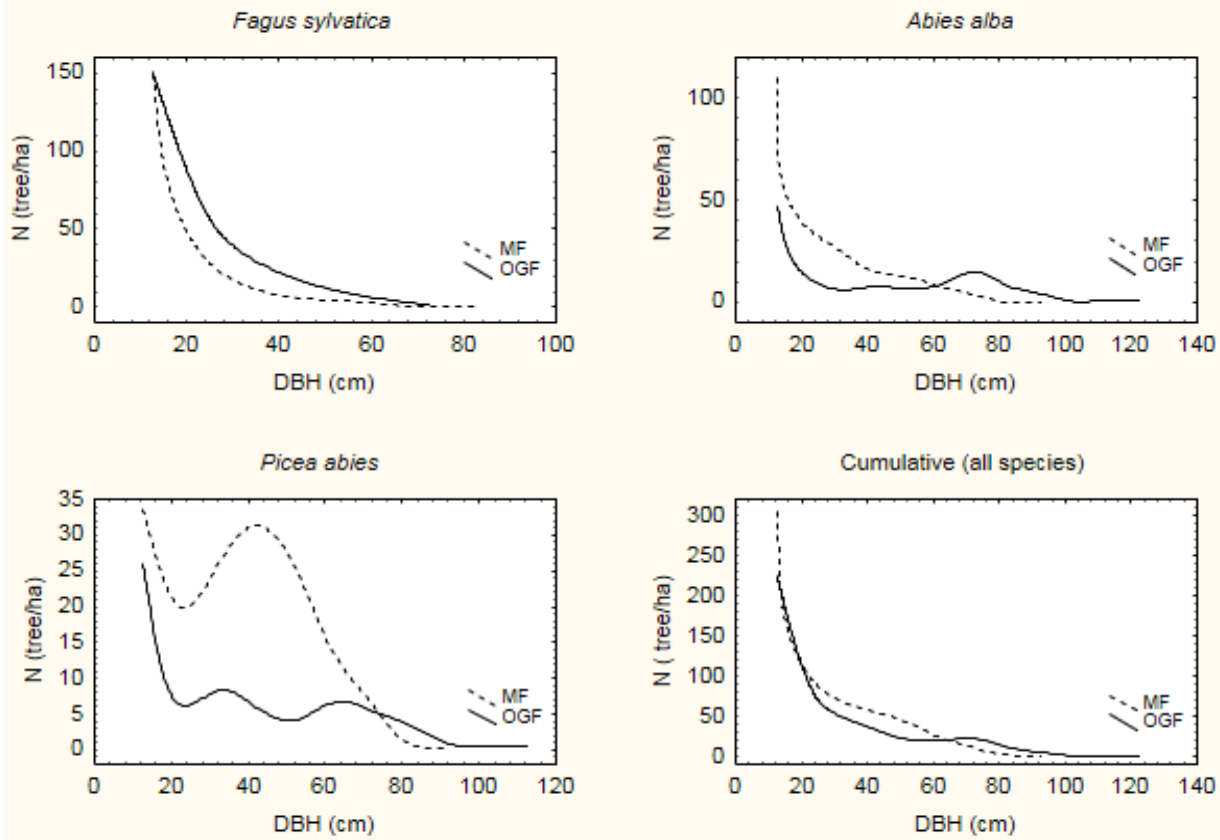

Figure 1. Diameter distributions in old-growth forests (OGF) Janj and Lom and adjacent managed forests (MF).

For overall species and species specific distributions RS shapes were prevalent. Beech had RS shape in 3 out of 4 locations. Fir had two non-sustainable dbh distributions (UNI and IQ), while spruce did not show sustainable distribution in any of the four cases (Table 4). 
Table 4. Parameters of the best-fitting model for multiple regressions between the base 10 logarithm of trees per hectare and all possible combinations of $\mathrm{DBH}, \mathrm{DBH}^{2}$ and $\mathrm{DBH}^{3}$ (DBH class span was $\left.10 \mathrm{~cm}\right)$ for oldgrowth forests (OGF) Janj and Lom and adjacent managed forests (MF).

\begin{tabular}{|c|c|c|c|c|c|c|c|c|}
\hline & \multicolumn{4}{|c|}{ MF Janj } & \multicolumn{4}{|c|}{ OGF Janj } \\
\hline & Fir & Spruce & Beech & Total & Fir & Spruce & Beech & Total \\
\hline RMSE & 0.03 & 0.04 & 0.01 & 0.03 & 0.18 & 0.14 & 0.07 & 0.11 \\
\hline Adj. $R^{2}$ & 0.99 & 0.99 & 1.00 & 0.99 & 0.86 & 0.85 & 0.99 & 0.97 \\
\hline N (DBH class) & 8 & 7 & 6 & 8 & 12 & 11 & 7 & 12 \\
\hline \multirow[t]{2}{*}{ Shape } & $\mathrm{RS}$ & IQ & RS & $\mathrm{RS}$ & UNI & UNI & $\mathrm{RS}$ & $\mathrm{RS}$ \\
\hline & \multicolumn{4}{|c|}{ MF Lom } & \multicolumn{4}{|c|}{ OGF Lom } \\
\hline RMSE & 0.18 & 0.18 & 0.15 & 0.16 & 0.33 & 0.22 & 0.04 & 0.21 \\
\hline Adj. $R^{2}$ & 0.92 & 0.94 & 0.96 & 0.96 & 0.74 & 0.85 & 0.99 & 0.94 \\
\hline N (DBH class) & 9 & 9 & 8 & 9 & 12 & 11 & 7 & 12 \\
\hline Shape & $\mathrm{NE}$ & UNI & $\mathrm{CO}$ & IQ & IQ & IQ & $\mathrm{RS}$ & $\mathrm{NE}$ \\
\hline
\end{tabular}

RMSE - root mean square error, UNI - convex or unimodal shape, RS - rotated sigmoid shape, IQ - increasing- $q$, CO - concave (sensu Janowiak et al., 2008)

The total number of large trees with DBH over $50 \mathrm{~cm}$ in OGF Janj amounted to 115 per ha (fir 64, spruce 37, beech 14), in OGF Lom 73 such trees/ha, while in MF Lom and Janj their frequency was 62 and 37 trees/ha, respectively. In the latter the trees with $\mathrm{DBH}$ above $80 \mathrm{~cm}$ were rare, while in OGF Janj there was 37, and in OGF Lom 13 such trees/ha. CV values considering diameters on whole plot area were similar between two OGF and significantly higher in OGF compared to MF (Janj area $t=7.13, p=0.0000$; Lom area $t=4.56, p=0.0002$ ). On the other hand, considering closest trees around central plot tree, OGF had greater only T1 and $\mathrm{T} 3$ diameter differentiation indices, while mean $\mathrm{T}$ indices and mean $\mathrm{M}$ indices had varied values and were overall similar between OGF and MF (Table 5).

Table 5. Mean diameter differentiation indices (T, T1, T2, T3), species intermingling indices (M), and coefficients of diameter variation on plot level $(\mathrm{CV})$ in studied forests

\begin{tabular}{ccccccc}
\hline & $\mathrm{T}$ & $\mathrm{T}_{1}$ & $\mathrm{~T}_{2}$ & $\mathrm{~T}_{3}$ & $\mathrm{M}$ & $\mathrm{CV}(\%)$ \\
\hline OGF Janj & 0.46 & 0.48 & 0.45 & 0.45 & 0.42 & 80.7 \\
MF Janj & 0.40 & 0.45 & 0.40 & 0.35 & 0.46 & 60.3 \\
OGF Lom & 0.50 & 0.56 & 0.47 & 0.47 & 0.51 & 78.3 \\
MF Lom & 0.54 & 0.53 & 0.50 & 0.45 & 0.38 & 67.2 \\
\hline T - Diameter differentiation index based on central tree and three nearest neighbor trees & & \\
T - Diameter differentiation index based on central tree and 1st nearest neighbor tree & & \\
T - Diameter differentiation index based on central tree and 2nd nearest neighbor tree & & \\
T - Diameter differentiation index based on central tree and 3rd nearest neighbor tree \\
M - Species Intermingling Index
\end{tabular}

\subsection{The patterns of tree species mixing}

Considering tree species composition based on tree number $(>7.5 \mathrm{~cm} \mathrm{DBH})$ non-significant results were obtained for pairs OGF Janj vs. OGF Lom and MF Janj vs. MF Lom, while significant differences were indicated for pairs OGF Janj $v s$. MF Janj $\left(\chi^{2}=26.77, p \leq 0.05\right)$ and OGF Lom $v s$. MF Lom $\left(\chi^{2}=16.81, p \leq 0.05\right)$. Significant outcomes of testing were also obtained when BA and GS were used as a criterion. The presentation of whole area averages across 
different strata (Fig. 3) showed clear dominance of beech in the middlestory of OGF Janj (88\%) and OGF Lom (70\%), while the situation for fir in the regeneration layer did not seem to be as adverse as in middlestory. It is also noticeable that maple occurred in regeneration of all studied forests, but gradually disappeared on its way to the upperstory in OGF. Nevertheless, in both MF small percentage of this species was present in the middlestory $(2.1 \%$ and $2.8 \%$ in MF Janj and Lom, respectively). In the upperstory of MF Janj it dropped to $0.2 \%$, while in MF Lom its share was maintained on the same level as in the middlestory. Spruce in the upperstory was dominant species along with fir and beech in OGF and MF; yet, its presence in the regeneration of all studied forests was rather sparse (Fig. 3).
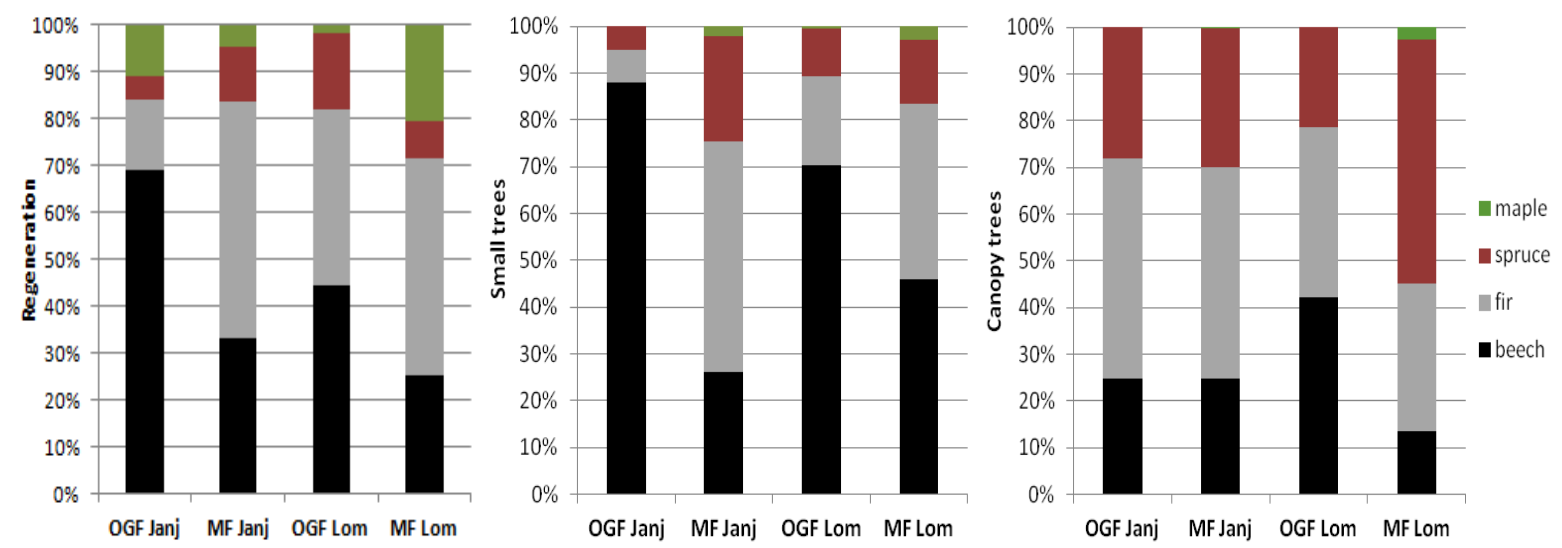

Figure 3. Tree species composition based on tree density in three stand layers: regeneration, small middlestory trees, and canopy trees.

The observations from Fig. 4 revealed strong tendency towards mixing of at least two species on the single plot area $\left(452 \mathrm{~m}^{2}\right)$. When considering stem number criteria, $15 \%$ of all plots in OGF Janj and only $5 \%$ in OGF Lom were monospecific plots. Beech was the only species that tended toward creation of pure cohorts. On the other hand, on 11.7\% of monospecific plots in MF Janj only fir exhibited such tendency. MF Lom had also low share of monospecific plots (6.7\%).

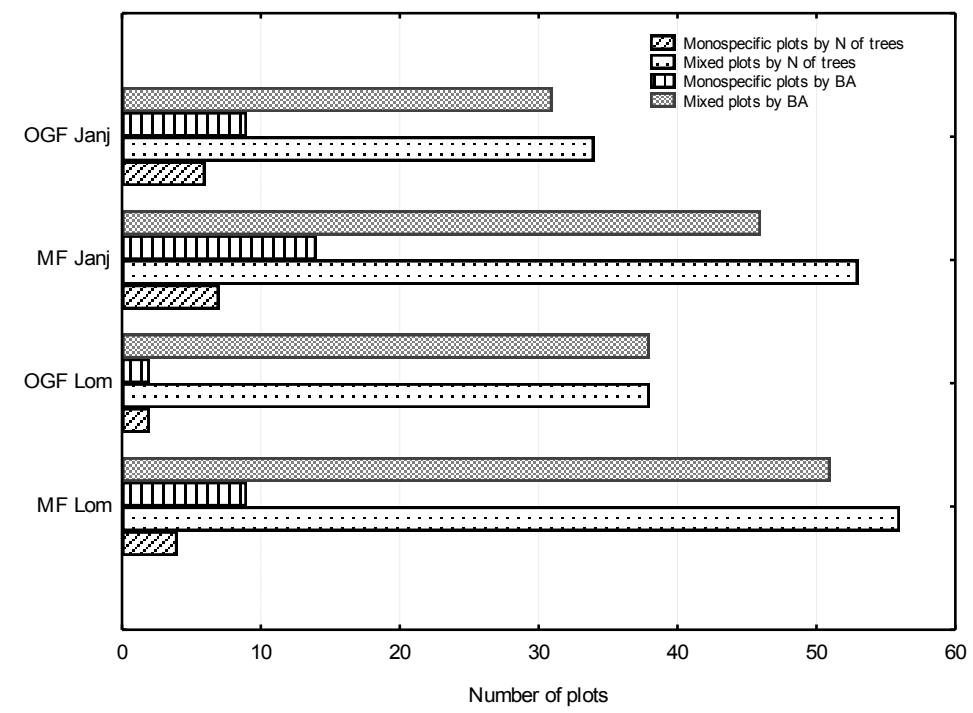


Figure 4. The share of mixed and monospecific plots based on stem number $(\mathrm{N})$ and basal area $(\mathrm{BA})$.

When considering BA as a criterion, in OGF Janj there were $17.5 \%$ of pure fir plots and $5 \%$ of pure spruce plots, while in OGF Lom we found only 5\% of pure fir plots. The shares of pure plots for fir, beech and spruce in MF Janj were 15\%, 1.7\%, and 6.7\%, respectively. In MF Lom there were $11.7 \%$ of pure spruce plots, while beech or fir formed only $1.7 \%$ of pure plots each (Fig. 4).

According to occurrence matrices, beech regeneration in OGF Janj had the highest chances to replace mature trees of all three species, whereas ratios for fir regeneration were lower and for spruce and maple fairly low. With the next higher stratum, chances of beech to replace mature trees were growing across matrices. Beech regeneration had the highest ratios of occurrence even under small trees indicating thus high level of endurability in suppressed conditions. Beech regeneration in MF Janj had highest relative frequences as well. However, in the middlestory fir took over with higher probabilities for canopy replacement, whereas chances of spruce in this layer only slightly increased compared to the regeneration layer (Table 6).

Table 6. Occurrence matrices for different stand layers in Janj area

\begin{tabular}{|c|c|c|c|c|c|c|c|c|c|}
\hline & & \multicolumn{4}{|c|}{ OGF Janj } & \multicolumn{4}{|c|}{ MF Janj } \\
\hline & & \multicolumn{8}{|c|}{ Regeneration (10 cm height- $7.5 \mathrm{~cm} \mathrm{DBH})$} \\
\hline \multirow{4}{*}{$\begin{array}{l}\text { Upperstory } \\
\text { Trees }\end{array}$} & & Beech & Fir & Spruce & Maple & Beech & Fir & Spruce & Maple \\
\hline & Beech & 0.73 & 0.14 & 0.07 & 0.06 & 0.53 & 0.23 & 0.11 & 0.13 \\
\hline & Fir & 0.69 & 0.11 & 0.09 & 0.11 & 0.47 & 0.33 & 0.14 & 0.05 \\
\hline & Spruce & 0.68 & 0.20 & 0.05 & 0.06 & 0.50 & 0.31 & 0.15 & 0.05 \\
\hline \multirow{5}{*}{$\begin{array}{l}\text { Upperstory } \\
\text { Trees }\end{array}$} & & \multicolumn{8}{|c|}{ Small trees $(7.5-27.5 \mathrm{~cm} \mathrm{DBH})$} \\
\hline & & Beech & Fir & Spruce & Maple & Beech & Fir & Spruce & Maple \\
\hline & Beech & 0.74 & 0.15 & 0.10 & 0.00 & 0.28 & 0.51 & 0.20 & 0.00 \\
\hline & Fir & 0.83 & 0.10 & 0.07 & 0.00 & 0.24 & 0.53 & 0.23 & 0.00 \\
\hline & Spruce & 0.83 & 0.09 & 0.08 & 0.00 & 0.28 & 0.34 & 0.38 & 0.00 \\
\hline \multicolumn{10}{|c|}{ Regeneration (10 cm height-7.5 cm DBH) } \\
\hline \multirow{4}{*}{$\begin{array}{l}\text { Small } \\
\text { Trees }\end{array}$} & & Beech & Fir & Spruce & Maple & Beech & Fir & Spruce & Maple \\
\hline & Beech & 0.63 & 0.16 & 0.10 & 0.11 & 0.48 & 0.29 & 0.16 & 0.06 \\
\hline & Fir & 0.75 & 0.13 & 0.04 & 0.08 & 0.50 & 0.33 & 0.08 & 0.09 \\
\hline & Spruce & 0.68 & 0.16 & 0.09 & 0.07 & 0.44 & 0.32 & 0.21 & 0.03 \\
\hline
\end{tabular}

In OGF Lom the occurrence odds for regeneration layer differed from those in OGF Janj in a way that beech regeneration in OGF Lom had slightly lower probabilities. What was interesting is that fir regeneration exhibited high tendency to replace not only mature beech and spruce trees, but fir trees as well (self-replacement). Nonetheless, in the middlestorey of OGF Lom beech played the most significant role and had by far highest odds to enter upperstorey from middlestory level. In neighboring MF Lom regeneration of beech was successful, but we can notice that under selective cutting the occurrence ratios for this species were lower in the middlestory compared to OGF Lom. Simultaneously, fir and spruce small trees had higher chances to occupy upperstorey in MF Lom than in OGF Lom (Table 7). 
Table 7. Occurrence matrices for different stand layers in Lom area

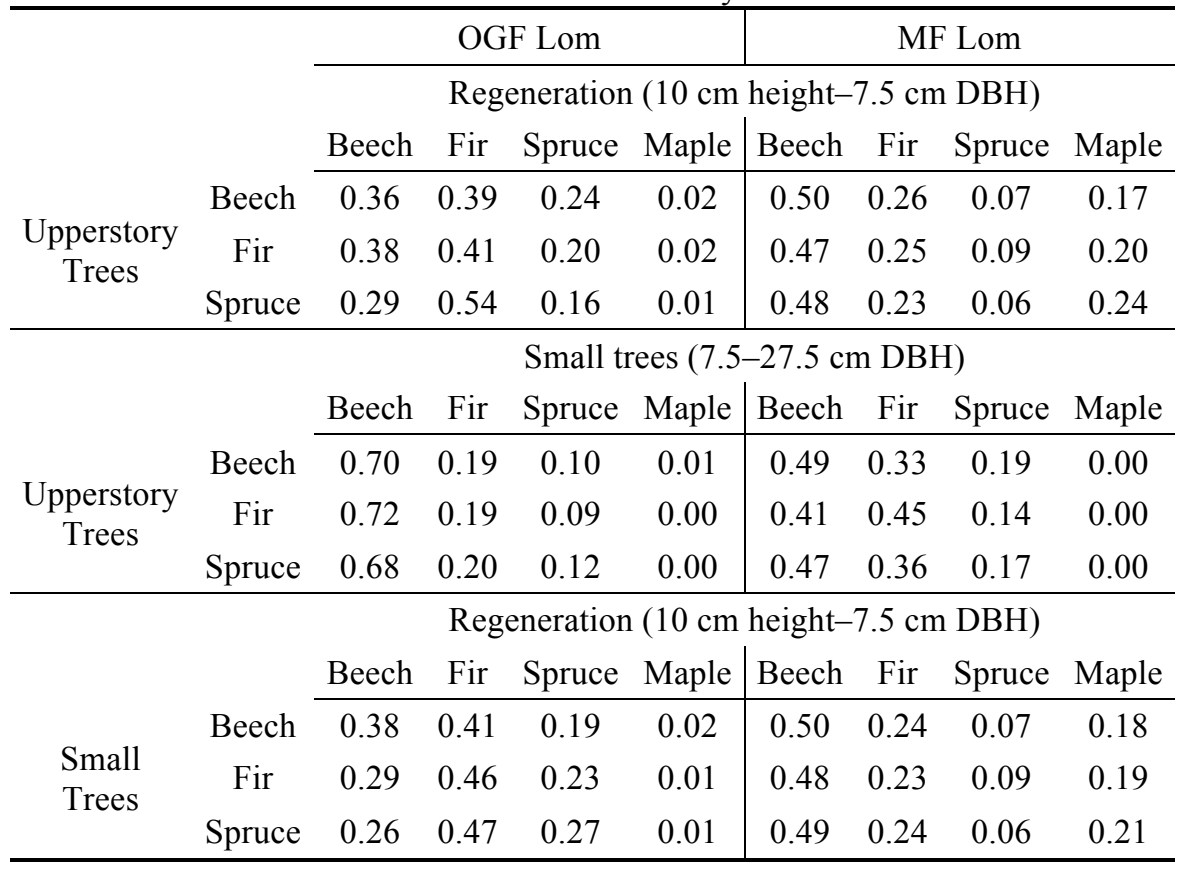

Fir BA proved to be a significant predictor of fir regeneration density. Namely, the density of fir regeneration was decreasing in both categories (up to $2 \mathrm{~m}$ height and from $2 \mathrm{~m}$ up to $7.5 \mathrm{~cm}$ $\mathrm{DBH}$ ) with the increase of fir BA. On the other hand, beech BA was positively associated with the density of beech and spruce regeneration up to $2 \mathrm{~m}$ height, whereas the ingrowth of spruce from $2 \mathrm{~m}$ up to $7.5 \mathrm{~cm}$ DBH was negatively influenced with the increase of beech BA. These results refer to plots in all four studied forests (Table 8).

Table 8. Results of the generalized linear multivariate analysis for regeneration from $10 \mathrm{~cm}$ up to $2 \mathrm{~m}$ height (Fir 2 $\mathrm{m}$, Beech $2 \mathrm{~m}$, Spruce $2 \mathrm{~m}$ ) and regeneration from $2 \mathrm{~m}$ height up to $7.5 \mathrm{~cm} \mathrm{DBH}$ (Fir $7.5 \mathrm{~cm} \mathrm{DBH,} \mathrm{Beech} 7.5 \mathrm{~cm}$ DBH, Spruce $7.5 \mathrm{~cm}$ DBH, Maple $7.5 \mathrm{~cm} \mathrm{DBH})$ predicted by beech BA and fir BA.

\begin{tabular}{|c|c|c|c|c|c|c|c|c|}
\hline \multicolumn{2}{|c|}{ Variables } & \multicolumn{7}{|c|}{ Dependent } \\
\hline $\begin{array}{c}\text { Indepen- } \\
\text { dent }\end{array}$ & Stats. & $\begin{array}{l}\text { Fir } \\
2 \mathrm{~m}\end{array}$ & $\begin{array}{c}\text { Beech } \\
2 \mathrm{~m}\end{array}$ & $\begin{array}{c}\text { Spruce } \\
2 \mathrm{~m}\end{array}$ & $\begin{array}{c}\text { Fir } \\
7.5 \mathrm{~cm} \\
\text { DBH }\end{array}$ & $\begin{array}{c}\text { Beech } \\
7.5 \mathrm{~cm} \\
\text { DBH }\end{array}$ & $\begin{array}{c}\text { Spruce } \\
7.5 \mathrm{~cm} \\
\text { DBH }\end{array}$ & $\begin{array}{c}\text { Maple } \\
7.5 \mathrm{~cm} \\
\text { DBH }\end{array}$ \\
\hline \multirow{3}{*}{$\begin{array}{l}\text { BA } \\
\text { Fir }\end{array}$} & intercept & -0.0389 & \multirow{3}{*}{ ns } & \multirow{3}{*}{ ns } & -0.0532 & \multirow{3}{*}{ ns } & \multirow{3}{*}{ ns } & \multirow{3}{*}{ ns } \\
\hline & std. error & 0.0097 & & & 0.0193 & & & \\
\hline & signif. & $* * *$ & & & $* *$ & & & \\
\hline \multirow{3}{*}{$\begin{array}{c}\text { BA } \\
\text { Beech }\end{array}$} & intercept & \multirow{3}{*}{ ns } & 0.0497 & 0.0568 & \multirow{3}{*}{ ns } & \multirow{3}{*}{ ns } & -0.1221 & -0.0437 \\
\hline & std. error & & 0.0203 & 0.0258 & & & 0.0464 & 0.0187 \\
\hline & signif. & & * & $*$ & & & $* *$ & $*$ \\
\hline
\end{tabular}

However, when only plots from two OGF were observed, GAM analysis revealed that BA of upperstory beech trees $>27.5 \mathrm{~cm}$ DBH had strong negative influence on the number of small middlestory beech trees from $7.5 \mathrm{~cm}$ to $27.5 \mathrm{~cm} \mathrm{DBH}\left(\mathrm{R}^{2}=0.36, p=0.0000\right.$; Fig. 5). Total BA 
and conifers BA in OGF did not negatively affect the number of middlestory beech trees. There was even slight positive association between conifers BA and number of middlestory beech trees, but this was neither strong nor statistically significant relation.

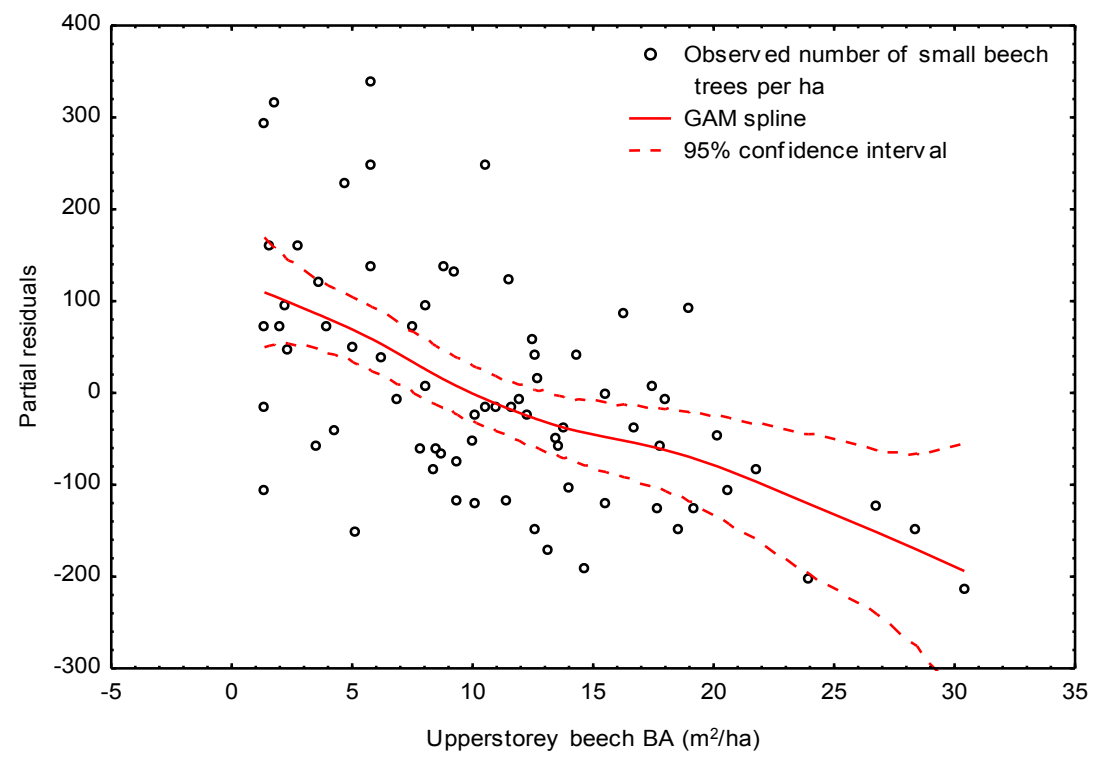

Figure 5. The negative association of basal area (BA) of upperstory beech trees $(>27.5 \mathrm{~cm} \mathrm{DBH})$ with the number of small middlestory beech trees (7.5-27.5 cm DBH) in old-growth forests Janj and Lom.

Beside shade-endurability reflected through occurrence matrices in the understory and middlestory, height curves represent another important indicator of tree species competitiveness. In that context, the conifers in the study area showed slower growth in younger stages, but in the long-run they regularly surpassed beech trees in the upperstory (Fig. 6).
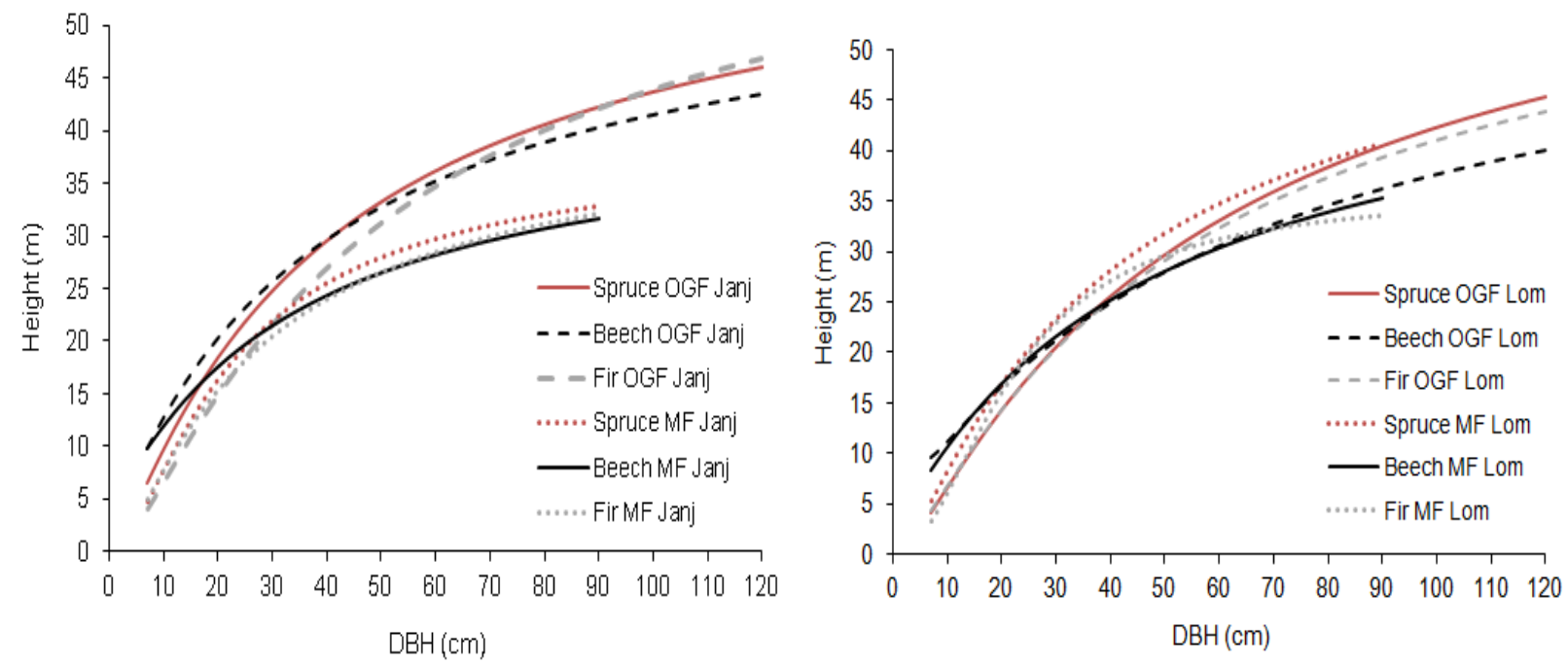

Figure 6. Height curves of beech, fir and spruce in old-growth forests (OGF) and managed forests (MF) in the study area. 


\section{Discussion}

\subsection{Structural characteristics}

The dominance of conifers in the upperstory and prevalence of late optimal phase resulted in very high GS in OGF Janj $\left(1215 \mathrm{~m}^{3} / \mathrm{ha}\right)$, which is probably close to a maximum that this forest can reach. In the future with ageing, dying of trees and progression of terminal phase, significant reduction in GS may be expected (Korpel, 1995), especially if beech replaces conifers in the upperstory to a larger extent. Currently, OGF Janj represents one of the most fertile European OGF (cf. Holeksa et al., 2009). On the other hand, OGF Lom was mostly characterized by selection phase and less favorable site conditions (results of PCoA not shown) resulting in GS of $763 \mathrm{~m}^{3} /$ ha, which is close to the average productivity of South-eastern European OGF (cf. Diaci et al., 2011). Much of the difference between the stocking levels may be attributable to site differences, but there is important contribution of species traits (Ducey et al., 2017) and the influence of species composition in different stand layers.

Developmental phases such as selection phase, optimal early phase, and optimal middle phase were present in both forest types, but MF differed from OGF by having a small number of plots with pole stage, however, late optimal phase and terminal phase were lacking in MF. Some researchers (e.g., Pintaric, 1978; Mayer et al. 1980; Schrempf 1986; Korpel, 1995) indicated that OGF are characterized usually by biomass accumulation and as a consequence they rarely exhibit selection phase and/or plenter structure. On the contrary, recent study by Paluch et al. (2015) in Western Carpathians suggested that stand structure of unmanaged forests exhibits considerable small-scale variability. Bončina (2000) reported that selection phase occupied 15\% of the area of Slovenian OGF Rajhenav Rog which was identical with the share of selection phase in OGF Janj, whereas this phase in OGF Lom covered as much as $37.5 \%$ of the area. In addition, even with high GS values these two OGF exhibited DBH distribution shapes considered to provide demographic equilibrium (RS and NE shape, respectively), and in this aspect were similar to neighboring MF (see also Goff \& West, 1975). In several other European mixed OGF the RS shape was most reported (e.g., Commarmot et al. 2005; Petritan et al. 2015), whereas Diaci et al., 2011 beside this form often reported the NE form. Similarly, RS and NE shapes were found to prevail in North-American OGF and in some MF as well (Goff \& West, 1975; Leak 1996; Goodburn \& Lorimer, 1999; Janowiak et al., 2008). Although the differences in the methodological approach can influence the determination of developmental phases as well as DBH distribution shapes (Goodburn \& Lorimer, 1999), the obtained results in this study corroborate the findings of the latter group of authors that indicated high complexity of interspecific relations due to which NE structure as well as selection phase are not rarity in OGF.

In MF the amount of GS and form of the diameter distribution depend on the management objective (O'Hara \& Gersonde, 2004), hence, it is not surprising that cumulative IQ shape occurs more often in such forests as large-diameter trees are usually removed (Leak, 1996; Janowiak et al., 2008). Although IQ shape may develop in OGF following the damage by windthrow as well (Diaci et al., 2011), fir and spruce in OGF Lom were characterized by this shape due to fluctuating densities of mid-sized trees. Therefore, beside the influence of disturbance, the forest structure is contingent on how long the understory and middlestory trees of constituent species are capable of shade-enduring before the release takes place (Canham, 1990; Ducey et al., 2017). In the present study we witnessed domination of fir and spruce in the upperstory, however, there 
was no hindrance for recruitment of small beech trees up to DBH of $27.5 \mathrm{~cm}$, even when GS was reaching very high values as it was the case in OGF Janj. Nevertheless, the increase of beech BA in the upperstory led to the decrease of small middlestory beech trees. Similar results were also obtained by Petritan et al. (2015) and Adamic et al. (2016). In addition, long-term study by Mitcherlich (1952) in mixed plenter forests showed that amount of GS in range from 200-600 $\mathrm{m}^{3} /$ ha did not have significant influence on ingrowth of young trees.

Füldner's DBH differentiation indexes were similar between OGF and MF, while mean CV values for whole plot area were significantly higher in unmanaged forests. Distinguishing feature was also found in the fact that MF always contained more trees in the smallest DBH class, whereas OGF were characterized with greater presence of trees in diameter classes $>50 \mathrm{~cm}$. This was expected as the presence of large-diameter trees is rather an attribute of OGF (Bauhus et al., 2009). OGF Janj dominated with large trees, while the values of this parameter in OGF Lom and both MF were similar to those reported in Slovenia (Adamic et al., 2016). It should be also noted that very large trees with DBH over $80 \mathrm{~cm}$ were rare but still present in MF (1-2 trees per hectare), yet, whether this is sufficient from the point of multi-functional forest management it goes behind the scope of this study.

Beside diameter structure, GS values also represent important indicators of forest structure. Optimal GS is supposed to allow satisfactory regeneration and ingrowth of young trees if sustainable structure is to be maintained. According to Schütz (1997), long-term structural stability in mixed spruce-fir-beech forests managed with plenter system should be attained at around $350-400 \mathrm{~m}^{3} /$ ha. These values are usually desirable if the major goal is maximum increment and wood quality, but it is important to indicate that in certain circumstances the plenter structure may be established at higher GS. Namely, MF Janj and Lom are comparable with some Swiss mixed forests that also retained equilibrium structure while simultaneously being characterized with high GS such as Neuenburger Jura plenter forest with $611 \mathrm{~m}^{3} / \mathrm{ha}$ and Emmental plenter forest with $674 \mathrm{~m}^{3} /$ ha (Schütz, 1969). Additionally, Bachofen (1999) proposed target GS of $563 \mathrm{~m}^{3} /$ ha for Hasliwald plenter forest in Switzerland. Likewise, target values for mixed fir-spruce-beech forests in Serbia may vary between $500-550 \mathrm{~m}^{3} /$ ha (Medarević et al., 2008). Consequently, following such silvicultural prescriptions could enable more effective maintenance of some old-growth characteristics in MF.

In the above context, our results were also compliant with some findings from the northern United States, but it remains unclear whether this capacity to sustain shade-tolerants at high stocking levels relates to reductions in maintenance respiration costs, differences in evapotranspirative demand, more even moisture availability through the growing season, or some other underlying mechanism (Ducey et al., 2017). However, based on the obtained results and available findings from other authors, we may corroborate the statements by Schütz (2002b) and O'Hara \& Gersonde (2004) that different amounts of GS can be held at demographic equilibrium, and hence different equilibrium diameter distributions can be developed for other forest types or other sites. 


\subsection{Tree species composition and mixing patterns}

Interspecific relations between beech, fir and spruce represent a complex subject as their coexistence is driven by the interaction of varied anthropogenic and natural factors (Vrška et al., 2009; Paluch et al., 2015; Nagel et al., 2016). Beside above-discussed structural characteristics, we investigated the influence of single-tree selection system on tree species composition and found that there was a significant (statistical) difference between MF and OGF in the areas of Janj and Lom. In that sense, our results were similar to those obtained by Burrascano et al. (2008) and Shifley et al. (1995), but different from Hale et al. (1999). The reason for different outcomes may be found in the observation made by Bončina et al. (2014) that selection management can importantly influence tree species composition by cutting preferences or by creating favourable conditions for regeneration and recruitment of some tree species. Consequently, certain differences regarding different stand parameters are possible as they directly depend on the management preferences at the local level, at least in MF.

Regardless of human influence, the observations from inventory plots indicated rather small share of monospecific plots considering either tree density or BA as a criterion for distinction in both forest types. In regeneration and pole stage, species coexistence largely depends on the level of shade-tolerance of established seedlings (Rozenbergar, 2012). Schütz (1969) found that suppressed growth phase lasted longer in OGF Janj compared to Swiss plenter forests. In the present study we did not focus explicitly on shade-tolerance of constituent species as no light measurements were included, but nonetheless the occurrence matrices reflected high ability of beech, fir and spruce to endure long shading under large canopy trees. Likewise, intermingling indices (M) that were similar between MF and OGF exhibited high values typical of single-tree mixture (cf. Pretzsch, 2009). These results indicated very high tendency of constituent tree species to mix with each other and one below other on a relatively small area corresponding to plot size of $452 \mathrm{~m}^{2} / \mathrm{ha}$. Such pattern is typical of selection forests (Schütz, 2001; Bončina, 2011), but this study further revealed that similar mixing pattern occurs in highly stocked OGF as well. In addition, diameter differentiation indices (T, T1, T2, T3) were similar between OGF and MF, and their values were also relatively high (cf. Pretzsch, 2009) indicating hence high diameter differentiation in the immediate tree neighborhood in both forest types.

Therefore, single-tree selection technique seems to be in accordance with natural processes as they indicated single-tree mixing of different diameters and different tree species. Consequently, creation of diverse equilibrium DBH structures should not be problematical as it demands only following the natural flow; yet, the problem occurred in the fact that such approach did not allow sufficient diversity of less shade-tolerant tree species such as spruce and maple in the upperstory (see also Brang et al. 2014). Thus, the application of silvicultural systems based on creation of larger canopy gaps may be necessary. It needs to be noted, though, that their application may be successful only if sufficient tending will be invested as the "realization of groups" will be probably encumbered by natural small-scale mixing of constituent tree species. We are aware, on the other hand, that different mixing and grouping patterns may exist (see Schütz, 2002b).

On a larger scale, some patterns in forest composition are more easily discerned by examining species groupings by size class, and although the cumulative diameter distribution may have the equilibrium form, individual species do not necessarily follow such form (Shifley et al., 1995). 
Likewise, both conifers in OGF Janj and spruce in MF Lom had UNI shapes without sufficient self-replacement possibility even from the understory. Both conifers in OGF Lom and spruce in MF Janj expressed IQ distribution; RS shape was characteristic for beech in both OGF and MF Janj, whereas in MF Lom this species had CO distribution. This structural indicator consequently suggests changes in future forest composition in favour of beech as conifers, especially more light demanding spruce, indicate less stable transition between the diameter classes in the long run (cf. Keren et al., 2014).

A number of studies dealing with the decline of fir and/or spruce due to climate change were already mentioned in this study, but we also have to draw attention to different results. For instance, Petritan et al. 2015 reported successful fir ingrowth in mixed OGF in Romanian Carpathians. Thus, the opposing facts indicate that the setback of conifers in European OGF may be either cyclical or spatially unequal as different regions across the continent may have experienced unequal natural and human-induced impacts (Vrška et al., 2009) including the climate change (Kovats et al., 2014), which altogether may have led to disparate development of similar forest types.

\section{Conclusions and Management implications}

The long-term application of single-tree selection system in MF Janj and Lom led to creation of complex diameter structures similar to those found in adjacent OGF, while it simultaneously caused statistically significant differences in tree species composition. OGF did not only exhibit sustainable cumulative DBH structures, but also selection phase on small (plot) area was not rarity. Consequently, such outcomes support the arguments of nature-based silviculture for establishing and maintaining complex stand structures in MF. Besides, the occurrence matrices indicated emphasized vertical layering and high tendency of mixing of at least two species on relatively small area both in MF and OGF. Still, which species will get the chance to occupy forest upperstory depends eventually on the dynamics and intensity of natural disturbances in OGF and silvicultural measures in MF. The study corroborated the findings from some other studies (e.g. Schwartz et al., 2005; Klopčič et al., 2015; Nagel et al., 2016) that single-tree removals do not promote sufficient recruitment of shade intolerant sycamore maple and midshade tolerant Norway spruce. Nonetheless, it is important to emphasize that this approach allowed low but constant presence of maple (see also Bončina et al., 2014), while in OGF this species was practically absent in middle- and upperstory.

In addition, assuming that the trend of warming climate will continue in the region (Castagneri et al., 2014; Kovats et al., 2014), new solutions may be necessary for the adaptation of vulnerable tree species, especially native spruce. Certainly, for forest managers in mountainous MF great challenge will remain the adequate regulation of tree species diversity along with maintenance of equilibrium structure. As indicated in the study area, planned removal of excessive small-sized beech trees had positive impact on the ingrowth of fir into middlestory of MF, and hence, singletree selection management with strong emphasis on species regulation in younger stages may help to mitigate or hold back long-term fir decline in the regions where it occurred.

However, in order to keep compositional stability on the landscape level the shares of native spruce and maple should be increased as well. In practice, there is still a strong penchant for 
single-tree selection system in most parts of Bosnian Dinaric Mountains, but simultaneously spruce and maple are both ecologically and economically highly valued species. For that reason, the application of group-selection or irregular shelterwood system may be considered by decision-makers in the future, at least on certain designated areas.

\section{References}

Adamic, M., Diaci, J., Rozman, A. and Hladnik, D. 2016 Long-term use of uneven-aged silviculture in mixed mountain Dinaric forests: a comparison of old-growth and managed stands. Forestry.

Angers, V.A., Messier, C., Beaudet, M., Leduc, A., 2005. Comparing composition and structure in old-growth and harvested northern hardwood stands in Quebec. For. Ecol. Manage. 217, 275293.

Bachofen H. 1999. Gleichgewicht, Struktur und Wachstum in Plenterbeständen. Schweizerische Zeitschrift für Forstwesen, 150, 5: 157-170.

Bauhus J., Puettmann K., Messier C., 2009. Silviculture for old-growth attributes. Forest Ecology and Management 258: 525-537.

Biolley, H. 1901 Le jardinage cultural. J. For. Suisse. 52, 67-104. 113-131.

Bolte A., Hilbrig L., Grundmann B., Kampf F., Brunet J., Roloff A. 2010. Climate change impacts on stand structure and competitive interactions in a Southern Swedish spruce beech forest. Eur. J. Forest Res. 129, 3: 261-276.

Bončina A. 2000. Comparison of structure and biodiversity in the Rajhenav virgin forest remnant and managed forest in the Dinaric region of Slovenia. Global Ecology \& Biogeography, 9: 201211.

Bončina A. 2011. History, current status and future prospects of uneven-aged forest management in the Dinaric region: an overview. Forestry, 84: 467-478.

Bončina A., Čavlović J., Čurović M., Govedar Z., Klopčič M., Medarević M. 2014. A comparative analysis of recent changes in Dinaric uneven-aged forests of the NW Balkans. Forestry, 87: 71-84.

Brang P., Spathelf P., Larsen J.B., Bauhus J., Bončina A., Chauvin C., Drössler L., GarciaGuemes C., Heiri C., Kerr G., Lexer M.J., Mason B., Mohren F., Mühlethaler U., Nocentini S., Svoboda M., 2014. Suitability of close-to-nature silviculture for adapting temperate European forests to climate change. Forestry 87(4):492-503.

Burrascano, S., Lombardi, F., Marchetti, M., 2008. Old-growth forest structure and deadwood: are they indicators of plant species composition? A case study from central Italy. Plant Biosystems 142, 313-323. 
Canham C. 1990. Suppression and Release During Canopy Recruitment in Fagus-grandifolia. Bulletin of the Torrey Botanical Club, 117, 1: 1-7.

Castagneri D., Nola P., Motta R., Carrer M. 2014. Summer climate variability over the last 250 years differently affected tree species radial growth in a mesic Fagus-Abies-Picea old-growth forest. Forest Ecology and Management, 320: 21-29.

Commarmot, B., Bachofen, H., Bundziak, Y., Bürgi, A., Ramp, B., Shparyk, Y., Sukhariuk, D., Viter, R., Zingg, A., 2005. Structure of virgin and managed beech forests in Uholka (Ukraine) and Sihlwald (Switzerland): a comparative study. For. Snow Landsc. Res. 79, 1/2: 45-56.

Diaci J., Rozenbergar D., Anic I., Mikac S., Saniga M., Kucbel S., Visnjic C., Ballian D. 2011. Structural dynamics and synchronous Silver fir decline in mixed old-growth mountain forests in Eastern and Southeastern Europe. Forestry, 5: 479-491.

Diaci J., 2011. Silver Fir Decline in Mixed Old-Growth Forests in Slovenia: an Interaction of Air Pollution, Changing Forest Matrix and Climate, Air Pollution - New Developments, Prof. Anca Moldoveanu (Ed.), InTech, DOI: 10.5772/17962.

Drinic P., Matic V., Pavlic J., Prolic N., Stojanovic O., Vukmirovic V. 1980. Tablice taksacionih elemenata visokih i izdanackih suma u SR BiH. Sarajevo, Sumarski fakultet: 102 p.

Ducey J. M., Woodall W. C., Bravo-Oviedo A., 2017. Climate and species functional traits influence maximum live tree stocking in the Lake States, USA. Forest ecology and management 386: $51-61$

Ficko A., Roessiger J., Bončina A., 2016. Can the use of continuous cover forestry alone maintain silver fir (Abies alba Mill.) in central European mountain forests? Forestry 89 (4): 412421.

Fröhlich J., 1954. Urwaldpraxis: 40-jahrige Erfahrungen und Lehren. Radebeul Neumann, Berlin, 199 p.

Goodburn, J.M. and Lorimer, C.G. 1999 Population structure in old-growth and managed northern hardwoods: an examination of the balanced diameter distribution concept. For. Ecol. Manag. 118(1-3), 11-29.

Hale C.M., Pastor J., Rusterholtz K.A., 1999. Comparison of structural and compositional characteristics in old-growth and mature, managed hardwood forests of Minnesota, USA. Can. J. For. Res. 29, 1479-1489.

Füldner K., 1995. Zur Strukturbeschreibung in Mischbeständen. Forstarchiv, 66: 235-240. 
Füldner, K., 1996: Die "Strukturelle Vierergruppe" - ein Stichprobenverfahren zur Erfassung von Strukturparametern in Wäldern. In: Beiträge zur Waldinventur. Cuvillier Verlag Göttingen. S. 13-30.

Goff F.G., West D. 1975. Canopy-understorey interaction effects on forest population structure. Forest Science, 21: 98-108.

Holeksa J., Saniga M., Szwagrzyk J., Czerniak M., Staszynska K., Kapusta P., 2009. A giant tree stand in the West Carpathians: An exception or a relic of formerly widespread mountain European forests? For. Ecol. Manage. 257: 1577-1585.

Hufnagl, L. 1893. Der Plenterwald, sein Normalbild, Holzvorrat, Zuwachs und Ertrag. Österreichische Vierteljahresschrift für Forstwessen. 10, 117-132.

Janowiak M.K., Nagel L.M., Webster C.R. 2008. Spatial scale and stand structure in northern hardwood forests: implications for quantifying diameter distributions. Forest Science, 54: 497506.

Keren S., Motta R., Govedar Z., Lučić R., Medarević M., Diaci J., 2014. Comparative structural dynamics of the Janj mixed old-growth mountain forest in Bosnia and Herzegovina: are conifers in a long-term decline? Forests 5:1243-1266.

Kimmins J.P., Rempel R.S., Welham C.V.J., Seely B., Van Rees K.C.J. 2007. Biophysical sustainability, process-based monitoring and forest ecosystem management decision support systems. The Forestry Chronicle, 83: 502-514.

Klopčič M, Simončič T, Bončina A, 2015. Comparison of regeneration and recruitment of shadetolerant and light-demanding tree species in mixed uneven-aged forests: experiences from the Dinaric region. Forestry, doi: 10.1093/forestry/cpv021

Korpel S., 1995. Die Urwälder der Westkarpaten. Gustav Fischer Verlag: Stuttgart; Jena; New York, $312 \mathrm{p}$.

Kral K., Vrska T., Hort L., Adam D., Samonil P., 2010. Developmental phases in a temperate natural spruce-fir-beech forest: determination by a supervised classification method. European Journal of Forest Research 129, 339-351.

Kovats, R.S., R. Valentini, L.M. Bouwer, E. Georgopoulou, D. Jacob, E. Martin, M. Rounsevell, and J.-F. Soussana, 2014: Europe. In: Climate Change 2014: Impacts, Adaptation, and Vulnerability. Part B: Regional Aspects. Contribution of Working Group II to the Fifth Assessment Report of the Intergovernmental Panel on Climate Change [Barros, V.R., C.B. Field, D.J. Dokken, M.D. Mastrandrea, K.J. Mach, T.E. Bilir, M. Chatterjee, K.L. Ebi, Y.O. Estrada, R.C. Genova, B. Girma, E.S. Kissel, A.N. Levy, S. MacCracken, P.R. Mastrandrea, and L.L. White (eds.)]. Cambridge University Press, Cambridge, United Kingdom and New York, NY, USA, pp. 1267-1326. 
Leak W.A., 1996. Long-term structural change in uneven-aged northern hardwoods. Forest Science, 42: 160-165.

Matic V., 1963. Osnovi i metod utvrdjivanja normalnog sastava za preborne sastojine jele, smrce, bukve i hrasta na podrucju Bosne. Sumarski fakultet i Institut za sumarstvo i drvnu industriju, VIII, 8, Sarajevo, Bosnia and Herzegovina.

Matthews J.D., 1999. Silvicultural systems. Clarendon Press: Oxford, 284 p.

Mayer, H., Neumann, M., Sommer, H.-G., 1980: Bestandesaufbau und Verjüngungsdynamik unter dem Einfluss natürlicher Wilddichten im Kroatischen Urwaldreservat Corkova Uvala/Plitvicer Seen. Schweiz. Z. Forstwes. 131: 45-70.

Medarević M., Bankovic S., Pantic D., Obradovic S. 2008. Mesovite sume cetinara i liscara u Srbiji. Sumarstvo, 60, 3: 17-30.

Mitscherlich, G., 1952. Die Tannen-Fichten-(Buchen) Plenterwald: eine ertragskundliche Studie. Schriftenreihe der Badischen Forstlichen Versuchsanstalt, 8: 1-42.

Motta R., Garbarino M., Berretti R., Meloni F., Nosenzo A., Vacchiano G., 2015. Development of old-growth characteristics in uneven-aged forests of the Italian Alps. Eur. J. For. Res. 134, $19-31$

Nagel, T.A., Mikac, S., Dolinar, M., Klopcic, M., Keren, S., Svoboda, M., Diaci, J., Bončina, A., Paulic, V., 2016. The natural disturbance regime in forests of the Dinaric Mountains: A synthesis of evidence. Forest Ecol. Manage. (2016), http://dx.doi.org/10.1016/j.foreco.2016.07.047

O’Hara K.L., Gersonde R.F., 2004. Stocking control concepts in uneven-aged silviculture. Forestry 77, 131-143.

Pach, M., Podlaski, R., 2015. Tree diameter structural diversity in Central European forests with Abies alba and Fagus sylvatica: managed versus unmanaged forest stands. Ecol. Res. 30(2):367384.

Paluch J. G., Kołodziej Z., Pach M., Jastrzębski R., 2015. Spatial variability of close-to-primeval Fagus-Abies-Picea forests in the Western Carpathians (Central Europe): a step towards a generalised pattern. Eur. J. Forest. Res. 134: 235-246.

Petritan I.C., Commarmot B., Hobi M.L., Petritan A.M., Bigler C., Abrudan I.V., Rigling A., 2015. Structural patterns of beech and silver fir suggest stability and resilience of the virgin forest Sinca in the Southern Carpathians, Romania. For. Ecol. Manage. 356, 184-195.

Pintaric, K., 1978. Urwald Perucica als natürliches Forschungslaboratorium. Allg. ForstZ. 33: 702-727. 
Puettmann, K.J., Wilson, S.M., Baker, S.C., Donoso, P.J., Drössler, L., Amente, G. et al. 2015 Silvicultural alternatives to conventional even-aged forest management-what limits global adoption? Forest Ecosystems, 2 (1), 1-16.

Pukkala, T., von Gadow, K. 2012. Continuous Cover Forestry. Springer, Dordrecht, pp. 296.

Pretzsch, H., 2009. Forest Dynamics, Growth and Yield. Springer, Berlin, Heidelberg, 664 pp.

Rozenbergar, D., 2012. Development and Tree Architecture of Beech in Late Sapling Phase in Uneven-aged Dinaric Silver Fir Beech Forests. Ph.D. Thesis, University of Ljubljana, Slovenia.

Schrempf W., 1986. Waldbauliche Untersuchungen im Fichten-Tannen-Buchen Urwald Rothwald und in Urwald-Folgebestanden. Verl. Verbandwiss. Ges. Österr., Wien, p. 147

Schütz J.Ph. 1997. Sylviculture 2. Lausanne, Polytechniques et Universitaires Romandes: 178 p. (in French)

Schütz J. P., 1999. Close-to-nature silviculture: is this concept compatible with species diversity? Forestry, 72 (4), 359-366.

Schütz, J. P. 2001. Opportunities and strategies of transforming regular forests to irregular forests. Forest ecology and management, 151: 87-94 .

Schütz J.P., 2002a. Silvicultural tools to develop irregular and diverse forest structures. Forestry 75: 327-337.

Schütz J.P., 2002b. Die Plenterung und ihre unterschiedlichen Formen. ETH Zentrum, Zürich, Switzerland, pp. 127. [in German]

Schütz, J.P., Saniga, M., Diaci, J., Vrška T., 2016. Comparing close-to-nature silviculture with processes in pristine forests: lessons from Central Europe. Annals of Forest Science. DOI: 10.1007/s13595-016-0579-9.

Schwartz J.W., Nagel L.M., Webster C.W., 2005. Effects of uneven-aged management on diameter distribution and species composition of northern hardwoods in Upper Michigan. Forest ecology and management, 211: $356-370$.

Shifley, S. R., Roovers L. M., Brookshire B. L., 1995. Structural and compositional differences between old-growth and mature second-growth forests in the Missouri Ozarks. Pages 23-36. in K. W. Gottschalk and S. L. C. Fosbroke, editors. Proceedings of the10th Central Hardwood Forest Conference, 5-8 March, 1995, Morgantown, WV, USA. USDA Forest Service General Technical Report NE-197.

Spathelf P., Bolte A., van der Maaten E., 2015. Is Close-to-Nature Silviculture (CNS) an adequate concept to adapt forests to climate change? Landbauforsch. App. Agric. Forestry Res. 65,161-170. doi: 10.3220/LBF1452526188000 
Szwagrzyk, J., Szewczyk J., Maciejewski Z., 2012. Shade-tolerant tree species from temperate forests differ in their competitive abilities: A case study from Roztocze, south-eastern Poland. Forest Ecology and Management 282: 28-35.

Tyrrell L.F., Crow, T.R., 1994. Structural characteristics of old-growth hemlock-hardwood forests in relation to age. Ecology 75, 370-386.

Vrška T., Adam D., Hort L., Kolar T., Janik D., 2009. European beech (Fagus sylvatica L.) and fir (Abies alba Mill.) rotation in the Carpathians-A developmental cycle or a linear trend induced by man? For Ecol Manage 258, 347-356.

White P.S., MacKenzie M.D., Busing R.T. 1985. Natural disturbance and gap phase dynamics in southern Appalachian spruce-fir forests. Canadian Journal of Forest Research, 15: 233-240.

Alessandrini, A., Biondi, F., Di Filippo, A., Ziaco, E., Piovesan, G., 2011. Tree size distribution at increasing spatial scales converges to the rotated sigmoid curve in two old-growth beech stands of the Italian Apennines. Forest Ecology and Management 262, 1950-1962.

Goff, F.G., West, D., 1975. Canopy-understory Interaction Effects on Forest Population Structure. Forest Science 21, 98-108. 